\title{
Lean Startup as a New Way of Managing Technology Ventures Illustrated by the Example of Wlcome App
}

\author{
Magdalena Popowska*, Patrycja Nalepa***
}

The dot-com bubble in the 1990s made the technology industry aware that even excellent ideas backed by amazing teams are not sufficient to ensure a startup's success. The biggest risk of startups is that they have to operate within many uncertainties, their market and customers are unknown, and their business model is not yet validated. Therefore, successful execution of such a venture requires a rigorous process that would validate different assumptions of the business idea. The Lean Startup method, introduced by E. Ries, gives the opportunity to eliminate some of the uncertainties and, therefore, to reduce the risks associated with starting a new business. Although this is not an easy method, as it requires minimum management knowledge and some analytical skills, it has become a highly recommended tool.

Keywords: Lean Startup, entrepreneurship, technology startups, Lean Canvas.

Submitted: 29.06.2015 | Accepted: 28.09.2015

\section{Lean Startup jako nowa metoda zarządzania firmami technologicznymi na przykładzie Wlcome App}

Bańka dot-com z lat dziewięćdziesiatych uświadomita przedsiębiorcom z branży technologicznej, że nawet doskonate pomysty realizowane przez niesamowite zespoty nie sa wystarczajace, aby zapewnić sukces startujacej firmie. Największe ryzyko dla start-upów stanowia liczne niewiadome, ich rynek $i$ klienci nie sa znane, a ich model biznesowy nie jest jeszcze potwierdzony. Sukces takiego przedsięwzięcia wymaga rygorystycznego procesu, który pozwoli na potwierdzenie różnych zatożeń pomystu na biznes. Metoda Lean Startup, wprowadzona przez E. Riesa, daje szansę na wyeliminowanie niektórych z niepewności, a zatem na zmniejszenie ryzyka zwiazanego z rozpoczęciem nowej działalności gospodarczej. Mimo że nie jest to metoda prosta, jako że wymaga ona minimalnej wiedzy z zarzadzania i pewnych umiejętności analitycznych, stała się ona wysoce zalecanym narzędziem.

Słowa kluczowe: Lean Startup, przedsiębiorczość, startupy technologiczne, Lean Canvas.

Nadesłany: 29.06.2015 | Zaakceptowany do druku: 28.09.2015

JEL: L25

\footnotetext{
Magdalena Popowska, PhD, Gdansk University of Technology, Faculty of Management and Economics. Adres do korespondencji: Gdansk University of Technology, Faculty of Management and Economics, ul. G. Narutowicza 11/12, 80-233 Gdańsk, mpop@zie.pg.gda.pl.

** Patrycja Nalepa, Alumnus.

Adres do korespondencji: p.nalepa@wp.eu.
} 


\section{Introduction}

The dot-com boom in 1995-2001 revealed that even the most innovative startups with amazing teams and remarkable products are still very prone to failure. Entrepreneurs were spending a massive amount of time developing a product or a solution that the market and customers then rejected. Investors were lost about where they should invest, as there was no formula that would help startups achieve success and profit. The waste of time, money and passion in that market place was enormous. However, this was slowly changing over the years as a new managerial technique for startups unfolded - Lean Startup, firstly coined by Eric Ries (2011). Lean Startup helps startups in minimizing waste, and reduces the risk of failure. The main assumption of this method is that each startup's success can be engineered if one follows a rigorous process.

Lean Startup tries to change the entrepreneur's mindset by putting focus on customers' wants and needs. In the past, it was the entrepreneur and his team who decided on the features of a new product and its overall look. Lean Startup, however, teaches entrepreneurs that in the end it is the customer who pays for the product; therefore, all should be done to benefit him. Furthermore, the product is tested on customers from the very early stages of product development to ensure this is exactly what customers would pay for.

Decision-making for startups is a relatively young research area. The latest and most frequently quoted literature covering this subject is made up by: Blank, 2005; Cooper \& Vlaskovits, 2010; Furr \& Ahlstrom, 2011; Ries, 2011; Maurya, 2012 and Blank \& Dorf, 2012. Therefore, this paper aims to present this new method of managing early-stage technology startups and challenge it based on an example of a real business case from the UK. Therefore, the theoretical background, introducing this method, is completed with a case study of Wlcome, a mobile app for coffee shops. This example is an application of the discussed method and is supposed to demonstrate its real value of analyzing and structuring the process of product or service development.

\section{Long lasting legacy of the dot-com era}

The ability to exploit technological opportunities is important for nations to expand their pool of businesses, stay competitive on the global market and grow the economy (Fagerberg et al., 2000). Meanwhile, there is a popular meme that 9 out of 10 startups fail. This information is unlikely to be true as no extensive research has been carried out to verify it. Nevertheless, many professionals and entrepreneurs cite this number as a reference to emphasize that the rate of failure is extremely high, in particular among internet-based technological ventures (Quora, 2012). This comes as no surprise, especially after dot-com era in the 1990s, when internet businesses got very popular and were thought to be an easy success. During that time, it was relatively easy to get funding from venture capitalists, and many entrepreneurs were building products too quickly while having little market knowledge (Donahoe et al., 2002). They then had to act even faster, and rapidly expand their customer bases in order to stay on the market, regardless of whether they were generating any profit at that stage. This was also due to the fact that investors wanted to have returns on their investments as fast as possible. In effect, many startups were scaling too fast and found themselves not being able to support their operations anymore. The dot-com bubble exploded and many of those businesses went bankrupt (Ewel, 2013).

Now venture capitalists are more cautious when investing in startups. While many may fear missing out on a next Google, eBay or Facebook, they are physically not able to invest in every idea they believe could become a tremendous success. Technology ventures, as opposed to other businesses, have a completely new business model, which is hard to benchmark against another business. Even if it seemed that a startup had a great product, amazing, determined team, brilliant technology, and the right idea at the right time, end even if everyone was working really hard on the product, this all did not guarantee any success.

First of all, it is important to recall what the main purpose of forming a venture 
is, namely to build a sustainable business. During that process, startups strive to develop a product or service a customer will be willing to pay for, which is often referred to as the Product/Market Fit ${ }^{1}$. By having paying customers, a startup is able to create profit and sustain its day-to-day operations. Only once the Product/Market Fit is achieved, the company should focus on expansion and scaling. However, many businesses struggle to do so, they work on a product or service that in their thinking is what people would want to buy. Moreover, entrepreneurs quite often try to scale too fast at the same time running out of cash, believing that at some point the sales of the product will soar. Then, if the product does not sell well or at all, the business goes bankrupt. Hard work, motivation and determination are not sufficiently good factors to convince customers to buy a certain product, and many entrepreneurs seem to forget that the product that perfectly addresses the needs of targeted customers is an essential basis for success (Blank, 2005).

There are only few examples of very successful technological startups that were built solely out of passion of their founders, who were lucky enough that their solution was liked by many customers. These entrepreneurs did not validate their product or service with the market first. On the contrary, they built the tool they liked and would want to use themselves. A great example of such an entrepreneur is Mark Zuckerberg, the founder of Facebook. Zuckerberg stated that: "We built it and we didn't expect it to be a company, we were just building this because we thought it was awesome" (Rao, 2011). During Facebook's early days, the early adopters, the very first people who used the product, were not decisive for the product development phase. Moreover, it could be argued that Facebook's tremendous success and popularity is in fact a coincidence, and it was not at the beginning engineered to become a company, which happened only after Facebook got popular within the group of first users.

During the dot-com era, as well as nowadays, many entrepreneurs get lost, as it seems that what they are doing should bring profit, and yet it does not. For a long time, there was no formula that would help technology ventures in their road to success - a formula that would be adjusted to the startup's short track record and many unknowns associated with this type of business, which resulted in entrepreneurs improvising while running their businesses. This was emphasized by Steve Blank (Blank \& Dorf, 2012), one of the main people who helped shaping the Lean Startup movement. Blank stated that even though there are many management tools taught at universities or in business books, they mostly are around 100 years old. Moreover, although they prove to be successful for big corporations, such as IBM, GM and Boeing, these management tools have little use for newly formed technology ventures. Blank points out that "founders have continually struggled with and adapted the big business tools, rules and processes taught in business schools and suggested by the investors. Investors have been shocked when startups failed to execute the plan, never admitting to the entrepreneurs that no startup executes to its business plan" (Blank \& Dorf, 2012, p. 19). Moreover, in the past it was believed that the main indicators of the likely success of a venture were solid strategy as well as in-depth market research, thus, many startups mainly focused on these elements. However, what these startups struggled to understand was that, with their uncertainties, it is nearly impossible to predict the future. On the other hand, some entrepreneurs trusted that the 'just do it' approach is the way a startup should be handled. However, this was not a successful formula either (Ries, 2011, p. 22).

Nowadays, more and more entrepreneurs realize that "startups are not simply smaller versions of large companies" (Blank \& Dorf, 2012, p. 19; Allen K.R., 2015, p. 287). The main difference between a startup and a large company is the number of previously mentioned crucial unknowns. Startups do not know who their customers are, what their problems are, or what features their product or service should have, while large companies are already trading, with their main focus on searching for repeatable and profitable business model. Therefore, the way newly formed businesses should be managed is different from established companies. 


\section{Searching for a repeatable formula for startup success}

Startup success for a long time had no repeatable method that could be used across different companies and industries. Eric Ries, the person who coined the term Lean Startup and introduced it in 2008 on his blog, realized that, for years, he had been working hard on products that would ultimately fail in the marketplace, regardless of how technologically advanced or promising they were. He believed that by creating an even better product and combining it with even harder work, the product should be successful. However, his increased efforts were not counteracting the fact that the developed products did not have the right Problem/Market Fit. As Ries got more and more dissatisfied with the traditional thinking, he decided to experiment with new approaches in his startup called IMVU, a social game where people were creating and playing with their avatars, and this is when Lean Startup was born. His new experimental approach resulted in a remarkable success of IMVU, and revenues above \$50 million in 2011 (Ries, 2011, p. 18).

In his book "The Lean Startup" Ries describes that traditional ways of managing a startup failed him, and therefore, he decided to look closer into the manufacturing industry, and Toyota's Lean Manufacturing concept, which was a revolutionary way of producing physical goods (Ries, 2011, pp. 16-20). The concept paid most attention to the value of the specific product, as the value is defined as any action or process that a customer would be willing to pay for. Therefore, all resources that do not contribute to the creation of the value for the end customer are considered to be wasteful and in effect eliminated. Lean Thinking, which is a wider concept with the same basis, was also used in other industries, such as healthcare or construction, where, for instance, Supply Chain Integration or Total Quality Management was being implemented. The main components of the lean movement also formed the core of Lean Startup, and these are (Virani, 2012): minimizing waste, the culture of continuous improvement, importance of measuring the big picture.

It is also worth mentioning that Ries was strongly influenced by Steve Blank, the author of "Four Steps to the Epiphany" regarding the Customer Development Process (Blank, 2005). Both entrepreneurs were based in Silicon Valley in California, a place that is famous for being a hub of many successful startups. Moreover, Blank was also mentoring Ries and his partner Will Harvey in their IMVU business as well as invested in it. In exchange, IMUV was the first startup to audit the Customer Development Process for one of Steve's classes at Stanford (Blank and Dorf, 2012, p. 78).

The main principle of Blank's Customer Development Process is a much higher focus on customers from the very first steps of business development, as an opposite of conventional thinking which was often "close your eyes and put the pedal to the metal" (Virani, 2012). This basically meant that the product was being developed without being verified on the market, and only once the product was out and marketed, the verification process would occur. A good example is Henry Ford's quote which, even though nearly a century old, still shows the thinking of many entrepreneurs, both before and still quite often nowadays: "If I had asked my customers what they wanted they would have said a faster horse" (Norton, 2015). Additionally, Henry Ford's great-grandson, Bill Ford Jr., added that "At Ford, we're going to figure out what people want before they even know it and then we are going to give it to them" (Norton, 2015). This shows that customers, in their thinking, were in no position to know what products they should be buying and the decision should be made for them instead. This is why Blank introduced a new way of thinking called Customer Development, which also forms the core of the Lean Startup movement. Both concepts agree that there is a lot of waste while setting up a new business, waste that is a measure of time, money, vision, passion and effort the business has to undertake in order to develop a product. Additionally, both schools answer the question how to limit the waste and increase the likelihood of success of the product.

\section{The essence of the Lean Startup}

Ries argues that the "Startup success is not a consequence of good genes or being in the right place at the right time. Startup suc- 
cess can be engineered by following the right process, which means it can be learned, which means it can be taught" (Ries, 2011, p. 13).

In essence, Lean Startup is about building successful businesses with minimal waste of time, money and effort. Moreover, the focus is also put on minimizing the risks associated with forming a new venture. Ries does not believe in coincidence in business, and he argues that even though startups have to deal with countless uncertainties, the future of the startup can be predicted if one follows the right process. The key is to test the product on the go, at all steps of the product development process, in order to make sure the product is one customers would ultimately buy.

What is important, most if not all startups have very scarce resources, and are often bootstrapping (Ries, 2011, p. 16). These resources are first of all the money the entrepreneur can spend on the product development, the marketing and team, the time which is the most important resource, and finally the effort and passion of the beginning entrepreneurs highly powered by excitement over their business idea that enable them to devote a significant amount of their time to developing their venture. Hence, it is essential to estimate where the waste in these resources occurs and counteract that.

Lean Startup is about accounting all business related ideas as assumptions, referred to as hypotheses. While it is impossible to test the whole business model, each individual component can be tested and validated separately. For that reason, Ries prepared a simple tool called Build-Measure-Learn, which helps the entrepreneur estimate whether he should continue with his current path with small product iterations or make a sharp turn into something else, called pivot. This loop is a very important part of validated learning. The startup builds different versions of the product which in reality are treated as experiments to see how customers react to them. The startup then measures the behavior of their customers and in effect can learn how to build a sustainable business. This information is more important than revenue itself, as it influences the next set of ideas and can reshape the product into a better one (Ries, 2011, p. 103). This is in accordance with continuous improvement which is one of the main principles of Lean Thinking and Lean Manufacturing that Ries based Lean Startup on.

To enter the BUILD in the quickest way possible, a minimum viable product (MVP) should be used. The MVP is "that version of the product that enables a full turn of the Build-Measure-Learn loop with a minimum amount of effort and the least amount of development time" (Ries, 2011, pp. 102-106). Therefore, the most important thing regarding the MVP is that it must be designed for validated learning. The role of the entrepreneur is to decide what he needs to learn first, and then design the experiment with a control group in order to measure the effects of that experiment (Kromer, 2012). The third, LEARN phase of the loop is at the same time the most important, as at this step the entrepreneur has to make a decision whether product iterations are enough to develop a product that would benefit their targeted customers, or he should pivot and reshape the idea. If the strategic hypothesis is correct, the entrepreneur is on the right path in product development; however, if it is false, a new strategic hypothesis needs to be created and tested (Ries, 2011, p. 106).

Ries described a step-by-step strategy the entrepreneur can follow to achieve his or her vision of a thriving and worldchanging business. For best results, this strategy should incorporate: a business model, a product roadmap, a point of view about partners and competitors and ideas about who the customer will be (Ries, 2011, p. 35). The outcome of this process is the Vision-Strategy-Product Pyramid. It is very important not to focus solely on the product from the beginning. Many entrepreneurs pre-maturely fall in love with the product, and if the product is not the right product, it is harder for them to realize that. It is worth reconstructing the product into the vision and strategy first, as it is the product that is changing the most, while the vision often stays the same, and the strategy is slightly modified (Maurya, 2012).

Ries introduces also four other main principles that form the Lean Startup method:

Entrepreneurs are everywhere: Entrepreneurs are visionaries, able to predict the future of their industries, prepared to undertake risks in their search for innovative solutions for their companies. What is more, being an entrepreneur is not about 
the skills one has, but about the vision he or she has, vision that their startup will change the world. These people are no longer working out of a garage, as it was popular in the $90 \mathrm{~s}$, but can be found everywhere, young or old, professionals and students (Ries, 2011, pp. 39-53).

Entrepreneurship is management: Startups are human institutions, and exactly as any other institution, they also should be managed. However, since traditional management would create bureaucracy or stifle creativity, a new kind of management should be used which is specifically designed to its context. Many entrepreneurs take the "just do it" approach, which only creates more chaos in the startup. Meanwhile, a startup is a portfolio of simultaneous activities. The entrepreneur is challenged by balancing all of them, and at the same time learning from his failures. In traditional management, a failure is considered a bad thing; however, for a startup it is a chance to get closer to the right product (Ries, 2011, pp. 26-38).

Validated learning: Much of waste many startups produce can be avoided by focusing energies on validated learning, learning when and where energy should be invested to minimize the waste of time and money (Ries, 2011, p. 104). In early-stage businesses revenue and profit is not an important goal in and of itself, as this is the end result of a product customers want. The goal is the viability of the business model, often referred to as traction. Startups operate under high uncertainty; therefore, validated learning is the essence of the startups operations. Customer feedback is important to know if the new product iterations are good. For example, if the product is software, it often happens that the programmer writes thousands of lines of code that customers do not want. Simply asking the customers what they want will not give exact answers, as customers often have no clue what they want unless they have it. For this reason, different experiments give a better picture of what is considered essential in a product. Moreover, failure is one of the best ways to learn a lot about the customer and the product.

Innovation accounting: Most entrepreneurs are optimistic by nature and standard financial accounting with forecasts and milestones is not really helpful. The reason for that is that the level of uncertainty is too significant, and these forecasts would not be accurate. Therefore, innovation accounting, specific for startups, needs to be implemented, so that the entrepreneur knows that the changes he made to the product are related to the results he is seeing (Ries, 2011, p. 156). Innovation accounting helps startups define measure and communicate progress from early days. Moreover, innovation accounting is also designed to hold entrepreneurs accountable (Maurya, 2012a). Generally, there are two main types of metrics for innovation accounting, and these are vanity metrics and actionable metrics. The main difference is that vanity metrics look good on paper, but do not present much insight, while actionable metrics are those that help in making decisions. On the other hand, a good example of actionable metric is, for instance, A/B split-test, where customers see different features of the product. From that, the entrepreneur can observe which feature set brings him more revenue (Ferris and Ries, 2009).

\section{Documenting the business model}

$A$ business model describes the rationale of how an organization creates, delivers, and captures value (...) The business model is like a blueprint for a strategy to be implemented through organizational structures (Cooper \& Vlaskovits, 2010, p. 14).

Business model is what distinguishes one company from another. The same idea can be executed in various ways, and the business model documents how the company is going to make profit. One way of documenting the business model is writing a business plan. However, since startups operate under high uncertainty, writing an elaborated business plan makes little sense. Therefore, it is advised that early-stage technology ventures use canvases instead. There are two main types of canvases that document the business model of the company, and these are Business Model Canvas (Osterwalder \& Pigneur, 2010) and Lean Canvas (Maurya, 212b). They both can be described as a one-page business plan, as they briefly describe nearly all aspects of a startup. They can also be used as a scorecard for the customer discovery process (Blank \& Dorf, p. 25) as they do not require the entrepreneur to get into the mind of his customers and confirm that 
his solution creates the value for these customers, but when updated regularly, the canvases show the changes and progress over time.

The main difference between the two canvases is that Business Model Canvas can be used for a wide selection of businesses at all stages, while Lean Canvas is more applicable for idea-stage startups. The reason behind it is that Lean Canvas captures the riskiest assumptions of the business model, which makes it more actionable for earlystage ventures.

\section{Customer discovery and business feasibility illustrated by the example of Wlcome mobile app}

Wlcome is a digital loyalty app that works without paper cards, QR codes, or NFC tags. Wlcome helps you build loyalty through relationship ${ }^{2}$.

Wlcome app is a mobile-based loyalty program that helps independent coffee shops recognize and reward their customers. The end-user submits his name and photo to the mobile app, and then when he enters the coffee shop, the barista is able to recognize him, so that he can be addressed in a more personalized way. The aim is to enable physical shops to provide an improved service and enhance the relationship with the customer. This should result in increased purchase size per customer as well as the frequency of visits.

The aim of the mobile loyalty solution is that the user does not need to carry his loyalty cards, as everything would be done automatically after the profile is set up. The loyalty program would be stamp-based, and the shop attendant can add new stars and view the old ones. Another important value proposition of the Wlcome app are referrals, which means that a user who refers a place to a friend who then makes a purchase would get a gift.

High Street Labs, the startup behind Wlcome, is based in London, United Kingdom. The team that worked on the product greatly varied throughout the time, as these were mostly interns. The first version of the mobile app was being developed in summer 2013, both for the end-user and the coffee shop. In terms of Customer Discovery the founder, Richard Russell, conducted a number of interviews; however, these were more sales pitches than exploratory interviews. Sales pitches show too much enthusiasm, and together with leading questions do not provide valuable data, and often the feedback from customer can be dishonest.

Loyalty programs are nowadays more and more popular among UK retailers, as they act as an incentive for their customers to come back more often and increase their spending. However, since many retailers now offer different sorts of loyalty programs, the customers are becoming more resistant and loyalty programs have become less incentivizing. There are numerous startups which tried and are still trying to innovate the customer loyalty market space. However, what the founder of Wlcome observed was little differentiation between different products, most of them either offered one loyalty scheme or stored all loyalty schemes in one place. Moreover, the aspect of personalization Wlcome aims to implement in physical shops, which is their differentiation factor, has already been widely used by online retailers. For instance, when visiting various websites, customers get notified that cookies would store their information in the browser.

Since physical shops are trying to increase the frequency of customers' visits, a good solution could be establishing more personal relationships with customers and 'at home' feeling. This creates a great chance for the Wlcome app, which enables coffee shops to interact with their customers and make them feel valued from the moment the customers enter the coffee shop. Furthermore, smartphones and tablets are being adopted much faster nowadays, which creates an increasing opportunity for the retailers to use these devices to their advantage.

\subsection{Case methodology}

Since one of the authors of this paper had an opportunity to work in London with a startup Highs Street Laps, developing the Wlcome app, the primary data was obtained through in-depth personal structured interviews with two potential customer segments representatives, being also qualified as the early-adopters: endcustomers and coffee shop owners and managers. The sample consisted of 15 individuals (in two age groups: $20-25$ and 26-30), 8 independent coffee shops and 6 
coffee shop chains. This research aimed at understanding both the customers' attitude towards loyalty schemes and the mindset of coffee shop owners.

To analyze the market and the industry attractiveness, Mullins' Seven Domains model (Mullins, 2010) was used. However, in this paper, because of the space limitation, the analysis was reduced to the necessary minimum. The data for the UK coffee shop market were easy to obtain through industry reports; however, the data for the loyalty programs, especially in the independent coffee shops, were not immaculate, as coffee shops often base their estimates on the overall financial performance instead of key metrics.

The market domain focuses on the buyers of the product, not the product itself. Therefore, these would be customer segments the startup wishes to serve (Mullins, 2010).

\subsection{Coffee shops market and trends}

In the last decade, the UK coffee shop market has been growing steadily. In 2012 the coffee shop market reached a growth of $7.5 \%$, which resulted in $£ 5.8$ billion in turnover. The number of coffee shops increased by $4 \%$ and expanded to 15,723 outlets in total. In general, the number of independent outlets increased by $26.5 \%$ from 4,453 to 5,633 over the last decade (2002-2012) and this number is said to increase by next $12 \%$ to 6,294 outlets by 2017. By 2017 it is expected that the total UK coffee shop market would exceed $£ 8$ billion in turnover, and the total number of outlets would be greater than 20,000 (Allegra Strategies, 2012).

It is estimated that currently around $1.5 \%$ of adults visit coffee shop at least four times a week in UK. On the other hand, some customers have been moving away from large coffee shop chains due to ethical reasons. This was seen especially after Starbucks tax-evasion scandal that came into light in 2012.

What is also noteworthy, only $3 \%$ of 25,000 surveyed people stated that loyalty cards are a decisive factor when choosing a coffee shop (Allegra Strategies, 2012). At the same time, a strong preference towards point-based loyalty schemes can be observed, where the reward is more tangible and can be translated directly into cash (eMarketer, 2012).
Mobile-phone-based loyalty solutions were chosen by $27 \%$ of respondents of eMarketer research carried out on a group of 1000 UK Internet Users. The mobile loyalty solutions were in particular popular with 18 to 34 year olds, where $43 \%$ of them were subscribed to at least one mobilephone-based loyalty scheme. Meanwhile, one of four respondents participated in a coffee shop loyalty program. This creates a strong opportunity for mobile applications rather than standard loyalty cards, especially that all of the 1000 internet users surveyed complained about carrying too many loyalty cards in their wallets (eMarketer, 2012).

Furthermore, the market research done by Mercator Advisory Group on American population revealed that in 2011 only $4 \%$ of them replaced their loyalty card with a mobile app; however, more than half $(53 \%)$ would be willing to do so (eMarketer, 2012).

Both the coffee shop market and the mobile loyalty market are perceived as attractive. The markets show a great potential for future growth; not only more coffee is consumed from coffee shops, but there is also an increasing demand from customers in terms of differentiated loyalty offerings. A strong preference for mobile solutions for loyalty is also in favor with Wlcome's Value Proposition. Furthermore, since coffee shops form a huge part of British lifestyle, coffee shops, in order to stay competitive, would need to compete using innovative solutions such as Wlcome. On the other hand, the market for independent loyalty coffee shops, compared with their insignificant marketing spending, is quite small, which might make it much harder for the startup to scale.

\subsection{Overall attractiveness of the industry}

The industry of Wlcome is defined narrowly by loyalty schemes offered in coffee shops. The geographical scope is both the UK and worldwide, due to mobile solutions being relatively easily transferable to other countries. The main competitors for Wlcome are other startups designing solutions for digital loyalty schemes.

The analysis of the industry at the micro and macro levels showed that the industry is only moderately attractive. The resources of High Street Labs as well as the team's capabilities are not distinctive, and the 
technology used in the development of the mobile app does not give a competitive advantage. The further analysis of the Porter's Five Forces revealed that the chosen industry is less attractive than expected. On the other hand, the industry is emerging and, therefore, will be subject to many changes that could benefit Wlcome. Furthermore, even in unattractive industries, there are many other ways of making profit. Hence, if Wlcome's solution is what coffee shops would pay for, they could become successful.

\subsection{Customer discovery and main assumptions}

In order to perform Customer Discovery for Wlcome, the main assumptions need to be analyzed and tested ${ }^{3}$. The early adopters of Wlcome who were chosen for Customer Discovery were divided into two main groups:

1. End-customers, who obtain the mobile application for free. Based on the market research, a greater emphasis was put on interviewing two age groups, 20-25 and $26-30$, as they not only visit coffee shops more regularly, but also choose independent coffee shops more often. In addition, the first age group, 20-25, is more price sensitive so may be more influenced by loyalty programs.

2. Independent coffee shops, which are the paying customers. The access to the decisive person (manager or owner) in independent coffee shops is significantly easier than in big chains. Furthermore, independent coffee shops need to compete with well-known chains, and they often want to offer superior service. On the other hand, their marketing budget is small, and independent coffee shops would not be able to develop a mobile loyalty app on their own.

During the process of developing first Lean Canvas, the main pain points for end-customers were identified in a form of initial assumptions: 1 . Customers are not fond of carrying loyalty cards; 2 . Customers would prefer to receive personalized service when visiting a coffee shop more frequently; 3 . Since numerous retailers are offering loyalty schemes, they have a much lower impact on the customer choosing one coffee shop rather than another.

The above assumptions are end-customer oriented, not buyer oriented (which would be independent coffee shops). The aim was to understand the customers' attitude towards loyalty schemes, and to see its impact on their behavior. The interviews showed that many customers choose one loyalty scheme to participate in, in order not to have too many loyalty cards clogging their wallets. On the other hand, many interviewees stated that they often forget to carry the card or to use it; therefore, they are less likely to sign up for any loyalty schemes. Furthermore, they declared that the fact of obtaining a loyalty card does not make them return to the coffee shop more often, as the benefits coming from a loyalty card are marginal. Therefore, all three assumptions were true, and the pain points did exist.

The initial assumptions for the second customer segment, independent coffee shops, were: 1 . Paper loyalty cards do not extensively increase sales of the coffee shop; 2. Coffee shops do not keep records of their regular customers; therefore, new baristas need to learn everything from scratch; 3 . New baristas find it hard to remember names of all regular customers or their usual orders. The goal was to understand the mindset of coffee shop owners. The findings showed that many independent coffee shop owners did not believe in loyalty schemes, and they often introduced them since their close competitors had them as well. The majority also agreed that they did not store any form of data on their customers; however, those who preferred addressing their regular clients by name did not find it hard to remember that piece of information. In addition, the owners did not pay much attention to metrics that could show the impact of the loyalty scheme on sales. Furthermore, none of the independent coffee shops had a problem with frequent staff turnover, and when the staff changed, there was usually another one or two people who knew regular customers and could train a new barista. Therefore, it was relatively easy to train new baristas as regards regular customers. As a result, only the first assumption was valid, and the remaining two were false.

During the process of interviewing endcustomers as well as coffee shops, new assumptions emerged: 1 . Independent coffee shops are aware that they need to build relationships with their customers; 2 . At the same time, these coffee shops struggle to do so; 3. Paper loyalty cards sometimes 
have fake stamps; 4. Mobile application for the loyalty scheme is too expensive.

Many independent coffee shop owners believe that a great service and more personal relationship is what distinguishes them from big chains and makes their clients come back more often. It is also important to know that $80 \%$ of customers are regulars. However, some coffee shops, especially bigger chains, find it a bit intrusive at times to get too personal with their customers and ask for their name. On the other hand, some independent coffee shop owners see remembering characteristics of the regular customers as a skill one can train. Quite often, even though names of the customers are not always known, their usual order is; therefore, the second followup assumption is false.

\subsection{Pain points of the customer segments}

Throughout the interviews with various customer segments, the authors were able to conclude what are the main pain points. For the end-user, the main pain point was the fact that the loyalty cards take too much space in the wallet, while still often offering marginal incentives. Some users were also concerned about the privacy issue, as some loyalty schemes require the user to give away his personal data. Another pain point was that customers felt that the personalization aspect was not sufficient, and they would prefer to be acknowledged when visiting a place regularly (fig. 1).

A pain point that was mentioned by coffee shops, especially small chains, is that they do not think introducing a loyalty program has any tangible benefit to their business. In their opinion, since coffee is not an expensive commodity, customers would buy it regardless of whether they got one coffee free after a certain number of vis-

Figure 1. Pain points of end-users

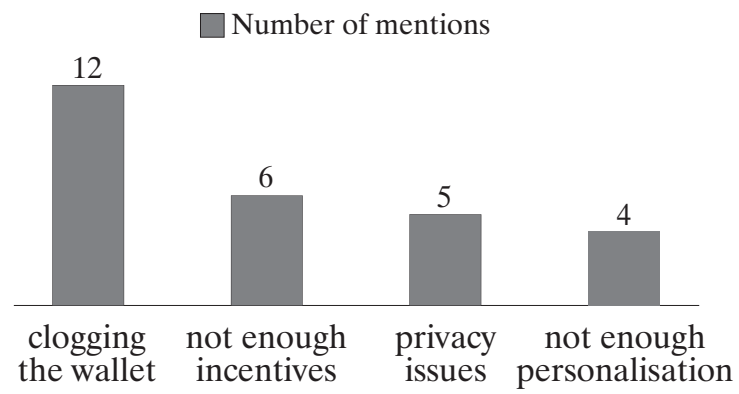

Source: own elaboration. its. Moreover, by introducing paper loyalty cards, they are not able to collect any valuable data on their customers; however, only bigger chains put more focus on the data on their customers, and would prefer to analyze them. Another problem with paper loyalty cards is that some of them have fake stamps, yet the costs of developing a mobile application would be too high (fig. 2).

Figure 2. Pain points of coffee shops

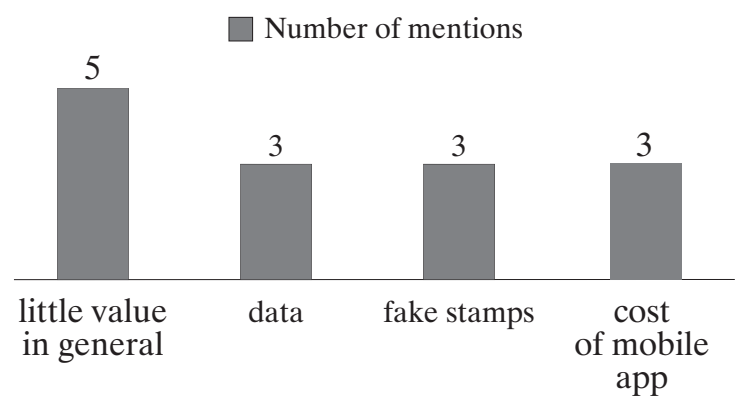

Source: own elaboration.

\subsection{Proposed solution}

Even though the mobile application of Wlcome was already being developed at the time of conducting Customer Discovery, changes that could be implemented are limited. Nevertheless, the Authors would like to present how the app could address the different pain points of end-customers and coffee shops (figures 3 and 4).

Since the end-customers are not paying customers, delivering the value to them is simpler. Moreover, if coffee shops decide to implement Wlcome, customers would use the app to receive gifts. The main benefits for the end-customers are that they would not need to remember to take the loyalty card with them each time they go to a coffee shop; instead, all would be done automatically, as the application would run in the background. Furthermore, from the moment they walk into the coffee shop, the barista would see their name and picture on the tablet, and thus would be able to greet them and offer a more personal touch.

Coffee shops are the paying ones; therefore, the solution has to benefit them in the best way possible. Since new loyalty schemes are becoming less and less incentivizing for customers, Wlcome could help make the experience more innovative, and 
Figure 3. Delivering value to end-customers

\begin{tabular}{|c|c|}
\hline $\begin{array}{c}\text { Too many loyalty } \\
\text { cards }\end{array}$ & - Mobile app solution \\
\hline $\begin{array}{c}\text { Little incentives to join } \\
\text { Privacy issues } \\
\text { personalization }\end{array}$ & $\begin{array}{c}\text { - Only name is required and picture } \\
\text { optional }\end{array}$ \\
\hline
\end{tabular}

Source: own elaboration.

Figure 4. Delivering value to coffee shops

$\begin{gathered}\text { Little value to } \\ \text { customers }\end{gathered}$
Fata
Fake stamps

Source: own elaboration.

make customers feel more appreciated. In addition, the mobile app would enable the coffee shops to collect a number of data on their regular customers, for instance, their coffee preferences, or which promotions affect them the most. Additionally, since many independent coffee shops are not able to develop a mobile app themselves, they could benefit from Wlcome by simply paying a monthly fee.

\subsection{Recommendations for Wlcome}

In the Authors' opinion, Wlcome app was in too early a stage to move to Customer Validation stage of Customer Development. Therefore, more experiments should be performed. Especially that Wlcome was being developed at that time, regardless of the outcome of Customer Discovery, the experiments could be done on the real mobile app instead to show the new purchasing experience.

The Product/Solution Fit, which is crucial in Customer Discovery, was not achieved. In addition, even though the founder already thought of the Solution, the Problems were not thoroughly under- stood. Therefore, the main focus for the Authors in Customer Discovery was to explore the Problem area, get to know the customers more, and analyze their behavior. For this reason, the in-depth interviews that were conducted and only the interviews with the $\mathrm{MVP}^{4}$ were to some extend focused on the solution.

There definitely is an opportunity for the Wlcome solution, as more and more businesses, for various reasons, recognize the need for implementing a loyalty scheme. Furthermore, since independent coffee shops have a small marketing budget, it is easier for them to use a technology where they only pay monthly. Also, even though one of the main assumptions regarding the baristas struggling to remember the regular customers' names proved to be false, the mobile loyalty solution became the main Value Proposition to customers. Therefore, no significant iterations within the app were needed; however, the Authors changed the way Wlcome was being addressed while presenting the MVP to customers.

Further steps for Wlcome should include, first of all, more experiments on 
the actual MVP of the mobile app in order to collect the necessary feedback. Additionally, new functionalities should also be explored, such as incorporating mobile payments or different reward schemes.

\section{Conclusions}

The aim of this paper was to introduce a new approach to building and managing earlystage technology ventures that, due to their specific nature, face different risks and challenges in comparison to established businesses. The Authors challenged this approach based on a real business case. Despite the fact that the case analysis had to be shortened to meet the edition requirements (much more analysis, including Porter's Five Forces model, SWOT analysis, was performed), the outcomes presented above seem to confirm that, thanks to Lean Startup method, many technology startup mistakes may be avoided at the definition stage. Unfortunately, while working on the Wlcome case, the Authors also realized that despite demonstrating to the entrepreneurs that the coffee shops would be unlikely to subscribe to their product (as the benefits for them are marginal), they still believed in their vision and version of it. Their justification, which can be commonly seen in many startups, was that the customers did not get a chance to experience the final product, which they otherwise would be delighted with.

It is worth mentioning as well, that even though more and more entrepreneurs are becoming aware of Lean Startup, their understanding of the concept is somehow distorted. The Authors met many entrepreneurs who felt lost in designing MVP and key experiments and in interpreting the findings.

Lean Startup has also another major criticism. The method gave entrepreneurs the right to failure. While the failure in the concept allows the entrepreneur to obtain valuable learning and unparalleled knowledge, it has become an excuse for some of them not to keep trying. Moreover, if the customer feedback is incorrectly collected, it will lead the entrepreneur to wrong assumptions, while it takes a great skill to know how to ask questions to get the feedback that the company really needs.

Furthermore, there are types of ventures that cannot be established on a small scale initially. Lean Startup, while applicable to many businesses, was primarily designed for web-based startups. Manufacturing companies would find it harder to follow the methodology, as they are more capitalintensive and cannot iterate as fast. Also, the type of innovation Lean Startup was designed for is user-driven incremental innovation in products or solutions, as it is extremely problem-focused and challenges customers' needs and wants. Radical innovation would be difficult to pursue with the Lean Startup method, as it often requires the development of a new technology.

Since each and every business is different, Lean Startup should be, therefore, used as guidance. Regardless of how good or bad the idea of the entrepreneur is, Lean Startup enhances the odds to become successful and provides startups with a great tool for managing the early-stage businesses. As Ries said "Great entrepreneurs don't have better ideas - they have better processes". However, the entrepreneur must always remember that the main reason for experiments and the MVP is to learn and discover in order to develop a great product.

\section{Footnotes}

1 Product/Market Fit refers to sufficient demand in a clearly defined marketplace for a product delivering a clearly defined value proposition to allow efficient (human or financial) capital expenditure to scale value creation.

2 Wlcomeapp, https://twitter.com/wlcomeapp (2014.07.28).

3 These assumptions are based on Lean Canvas that can be found in Appendix 1.

4 The Authors prepared two versions of clickable power point presentations (mock-ups) that, if launched on the phone, would show exactly how the app would work.

\section{References}

Allen, K. R. (2015). Launching New Ventures: An Entrepreneurial Approach. Cengage Learning.

Allegra Strategies (2012). Project Cafe 12. London: Allegra Strategies.

Blank, S. (2005). The Four Steps to the Epiphany: Successful Strategies for Products that Win, ISBN: 0976470705.

Blank, S. \& Dorf, B. (2012). Startup Owner's Manual. California: K\&S Ranch Inc.

Cooper, G. \& Vlaskovits, P. (2010). The Entrepreneur's Guide to Customer Development, ISBN: 0982743602, http://www.enactusryerson.ca/wp- 
content/uploads/2014/03/Guide-Customer-Development.pdf (2015.05.19).

Donahoe, J., Schefter, P. \& Harding, D. (2002). The last Legacy of the Dotcom Era, Across the Board, January/February 2002, www.accrosstheboardmagazine.com (2015.05.23).

eMarketer (2012). UK Brands Find Success with Loyalty Programs. eMarketer, New York.

Ewel, J. (2013). What's Lean About Lean Startup? http://www.agilemarketing.net/lean-lean-startup/ (2015.04.22).

Fagerberg, J., Guerrieri, P. \& Verspagen, B. (2000). The Economic Challenge for Europe, Adapting to Innovation based Growth. Edward Elgar Publishing Ltd, ISBN 1840645903.

Ferris, T. \& Ries, E. (2009). Vanity Metrics vs. Actionable Metrics. http://fourhourworkweek. com/2009/05/19/vanity-metrics-vs-actionable-metrics/ (2015.05.28).

Furr, N. \& Ahlstrom, P. (2011). Nail It then Scale It: The Entrepreneur's Guide to Creating and managing Breakthrough Innovation, ISBN: 0983723605.

Norton, K. (2015), Business Charisma. The Magnetism of Personality, Presence, and Customer Engagement. How Great Organizations Engage and Win Customers Again and Again. eScholars LLC.

Kromer, T. (2012). Build Measure Learn vs. Learn Measure Build. http://grasshopperherder.com/buildmeasure-learn-vs-learn-measure-build/ (2015.04.28).

Maurya, A. (2012). The Lean Stack - Part 1. http:// practicetrumpstheory.com/2012/06/the-lean-stack/ (2015.05.29).
Maurya, A. (2012a). How We Use Lean Stack for Innovation Accounting. http://practicetrumpstheory.com/2012/09/how-we-use-lean-stack-for-innovation-accounting/ (2015.05.28).

Maurya, A. (2012b). Why Lean Canvas vs. Business Model Canvas. http://practicetrumpstheory. com/2012/02/why-lean-canvas/ (2015.05.11).

Mullins, J. W. (2010). The New Business Road Test. Pearson.

Osterwalder, A. \& Pigneur, Y. (2010). Business Model Generation. New Jersey: John Wiley \& Sons Inc.

Quora (2012). What is the truth behind "9 out of 10 startups fail"? http://www.quora.com/What-is-thetruth-behind-9-out-of-10-startups-fail (2015.04.22).

Rao, L. (2011). Facebook's Zuckerberg: If I Were Starting A Company Now, I Would Have Stayed In Boston. http://techcrunch.com/2011/10/30/facebooks-zuckerberg-if-i-were-starting-a-companynow-i-would-have-stayed-in-boston/ (2015.04.23).

Ries, E. (2009). Validated learning about customers. Startup Lessons Learned. http://www.startuplessonslearned.com/2009/04/validated-learning-aboutcustomers.html (2015.05.30).

Ries, E. (2011). The Lean Startup. New York: Crown Business.

The Lean Startup Methodology. http://theleanstartup.com/principles (2015.05.29).

Virani, S. (2012). The History Of Lean Startup (and how to make sense of it all). http://saintsal.com/thehistory-of-leanstartup-and-how-to-make-sense-ofit-all/ (2015.04.24). 


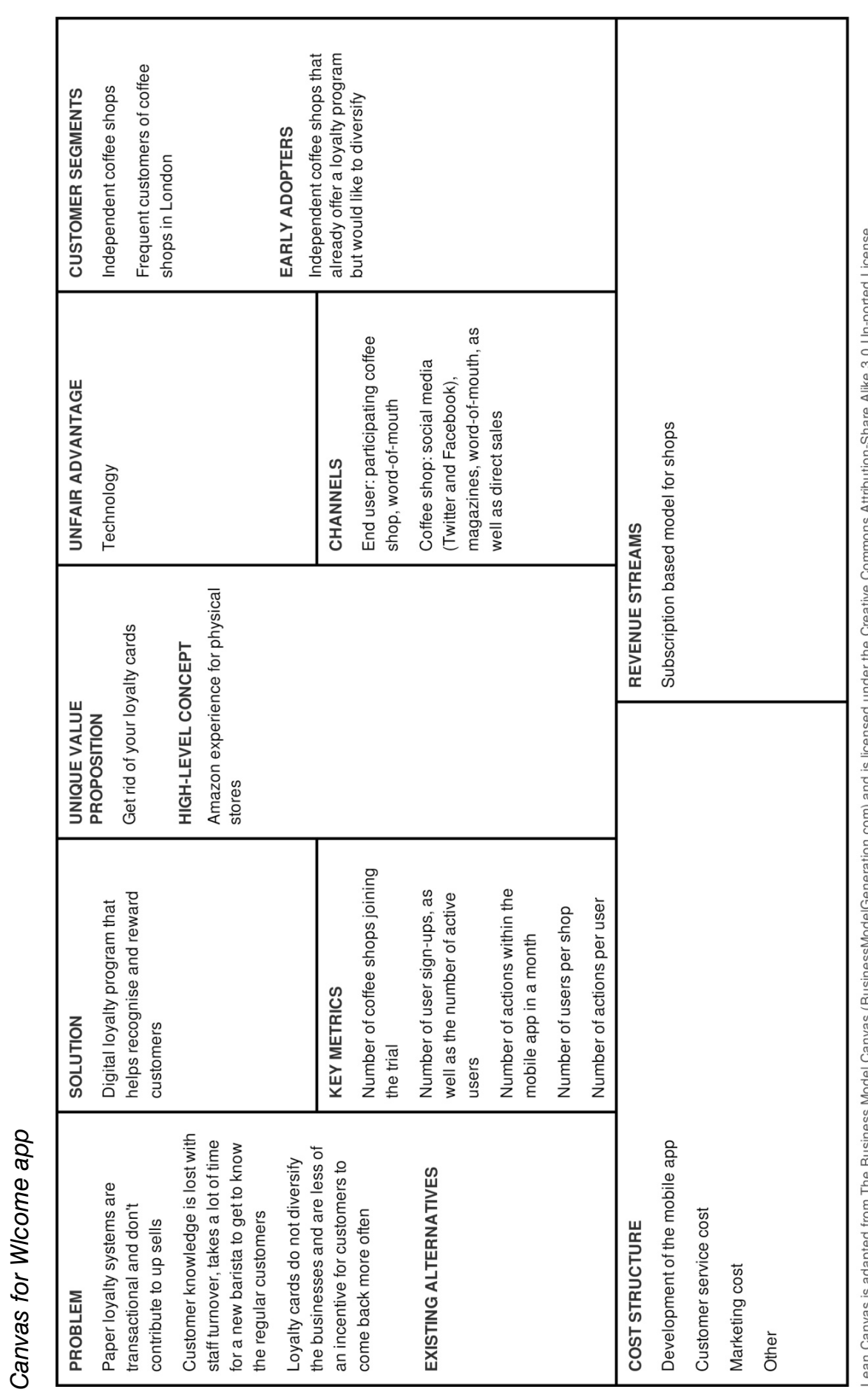

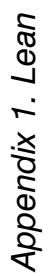

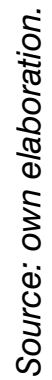




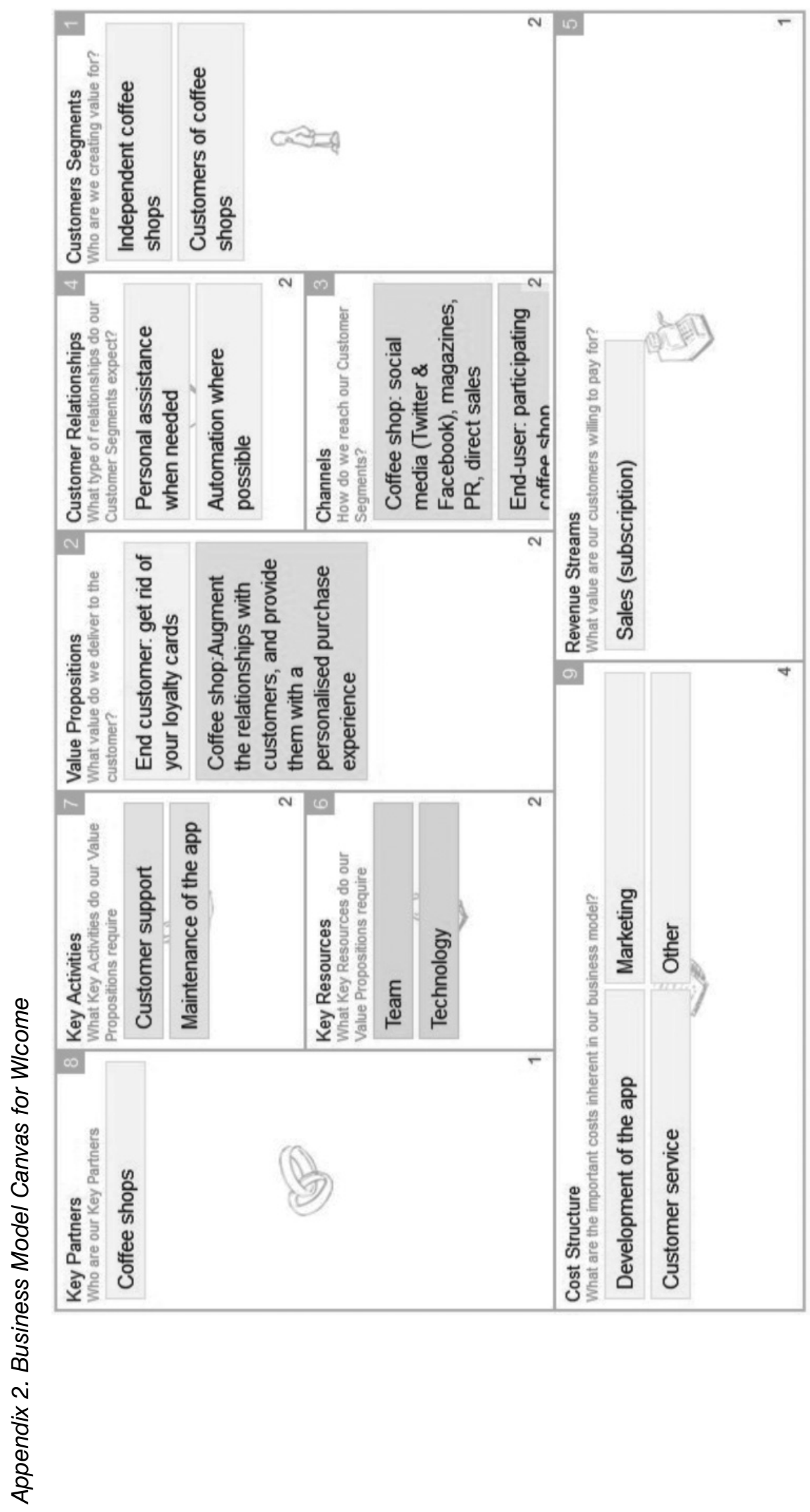

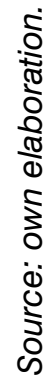

